\title{
Effect of Selinum on Ovarian Structure, Function and Serum Osteopontin Level in Rat Model of Polycystic Ovary Syndrome
}

\author{
SAMA S. KHALIL, M.D.*; NANEES F. EL-MALKEY, M.D.*; MOHAMED AREF, M.D.** and \\ HANIM M. ABD EL-NOUR, M.D.*** \\ The Departments of Physiology* and Biochemistry***, Faculty of Medicine, Zagazig University and \\ The Department of Anatomy, Faculty of Veterinary Medicine**, Zagazig University, Zagazig, Egypt
}

\begin{abstract}
Background: Selenium supplementation could be effective on reproductive function, however, its effect on serum Osteopontin (OPN) level in Polycystic Ovary Syndrome (PCOS) is not studied yet.

Aim of Work: The present study examines the effect of selinum on ovarian structure and function, in addition to its effect on OPN level in letrozole-induced PCO rat model.

Material and Methods: Thirty albino rats were included in the study and divided into 3 groups: Group (I): Normal control group, Group (II) PCOS group and Group (III): PCOS treated group with intra peritoneal (i.p.) sodium selenite $(0.3$ $\mathrm{mg} / \mathrm{kg}$ ) for 14 days after PCO induction, which was induced by oral letrozol $(1 \mathrm{mg} / \mathrm{kg})$ daily for 21 consecutive days. At the end of the experiment physical parameters (body weight, duration of oestrous cycle, ovarian and uterine weights) were estimated, metabolic parameters (glucose, insulin and calculated HOMA-IR), hormonal profile (total testosterone, $17 \mathrm{p}$ estradiol, progesterone, FSH and LH), inflammatory mediators (OPN and C-Reactive Protein (CRP)), and finally macro anatomical and micro morphological studies of the ovaries were done.
\end{abstract}

Results: There was a significant increase in serum FSH, $\mathrm{LH}$, testosterone, CRP, OPN, body weight and duration of esterous cycle with significant decrease in estradiol, progesterone level and uterine weight accompanied by appearance of multiple ovarian cysts and disappearance of corpus luteum in histological studies in Group II. However, selinum treatment for fourteen days reversed the above mentioned findings except for body weight. Moreover, OPN showed a significant positive correlation with FSH, LH and CRP. While it showed a significant negative correlation with estradiol and progesterone in both Group II and III.

Conclusion: Treatment with selinum exerts beneficial effects in PCOS rats which might be due to its antiinflammatory properties.

Key Words: PCO-Osteopontin-Selinum.

Correspondence to: Dr. Hanim M. Abd El-Nour, E-Mail: haneenmizo@gmail.com

\section{Introduction}

POLYCYSTIC Ovary Syndrome (PCOS) is a common gynecological, endocrine and metabolic disorder in women, it is influencing 6-18\% of women at reproductive age $[\mathbf{1 , 2}]$. It is an important cause of ovulatory and menstrual irregularity, subfertility and infertility, clinically evident hyperandrogenism and gonadotropin abnormalities [3] In addition, PCOS is an inflammatory disorder associated with Insulin Resistance (IR), glucose intolerance, obesity, and dyslipidemia, which may be related to higher risk of developing cardiovascular disease and type 2 diabetes [4,5]. Although several studies presented in this issue, the pathophysiological mechanisms of PCOS are still unknown [6,7].

Osteopontin (OPN) is a glycoprotein that has a functional role in multiple physiological and pathological events such as bone mineralization, atherosclerotic process, inflammation, IR, and malignant diseases [8,9]. It is a pro-inflammatory cytokine and is expressed in various tissues including bone, bone marrow, vascular tissues, kidney, ovary, activated macrophages, and T-lymphocyte [9].

Interestingly, Kuwabara et al., [10] reported that there is a link between OPN and ovarian function, as its expression in mouse ovaries and circulating levels were increased after gonadotropin administration.

Additionally, Selenium (Se) is an essential trace element, which has important biological effects on human health. Recent studies has been presented that selenium may affect several gynecological and obstetric complications including male and female infertility [11,12]. However, data on the 
beneficial effects of Se supplementation on biomarkers of inflammation, metabolic profiles and oxidative stress in human and animal studies are conflicting [13,14].

So the present study was designed to estimate serum OPN level and its possible association to hypophyseal-ovarian axis and to determine the effects of Se supplementation on macroanatomical and/or microscopic ovarian structure, hormonal disturbances and inflammatory markers in PCOS rat model.

\section{Material and Methods}

Animals: A total number of 30 female albino rats of local strain weighing 190-220g, were obtained from the Animal House of Faculty of Veterinary Medicine, Zagazig University. The animals were kept in steel wire cages (4 rats/cage). They were housed in room temperature with natural light/dark cycles. They had free access to food and water. All rats received care in accordance with the national health guidelines and the study protocol was approved by the Institutional Review Board and Ethics Committee of Faculty of Medicine Zagazig University, the study was conducted in the period from November 2017 to January 2018. The rats were accommodated to laboratory conditions for two weeks before the experiments was started.

Study protocol: Adult rats which had two sequential regular 4-5 days estrous cycles, confirmed using vaginal cytology, were subdivided into 3 groups: Group I $(n=10)$ : Normal control group in which rats were given $1 \mathrm{ml}$ of $1 \%$ Carboxy Methyl Cellulose (CMC) orally all through the experiment. Group II ( $\mathrm{n}=10)$ : PCOS group, and Group (III) $(\mathrm{n}=10)$ : PCOS rats treated with intra-peritoneal (i.p.) sodium selenite $(0.3 \mathrm{mg} / \mathrm{kg}$ bodyweight) (Sigma-Aldrich) for 14 days [15] starting from day 21 of the study after approval of PCO by vaginal smear. At the same time control rats received i. p. saline as well.

Induction of $P C O$ : It was induced by gavage letrozole (non-steroidal aromatase inhibitor) (ACDIMA international) $(1 \mathrm{mg} / \mathrm{kg}$ dissolved in $1 \%$ CMC) for 30 consecutive days [16] .

Determination of the sexual cycle: Smears were obtained daily at 9 a.m. by vaginal washing using saline and fresh unstained samples were evaluated microscopically during the experimental period, cycles with duration of 4 days were considered regular [17]. The four phases of the estrus cycle according to Goldman et al., [18] are as follow:
I- The proestrus phase: The vaginal smear shows many live epithelium with smooth margins.

II- The estrus phase: The vaginal smear shows large cornified (keratinized) cells with irregular margins.

III- The metaestrus phase: The vaginal smear shows many cornified cells plus infiltration of leukocytes.

$I V$ - The dioestrus phase: The vaginal smear shows absence of the cornified cells and presence of small leukocytes. The observation of cornified cells in the smears during a minimum of 10 consecutive days was defined as persistent estrus, indicating development of PCO [19] .

Blood sampling: At day 37 from the beginning of the intervention, $24 \mathrm{~h}$ after the last dose of sodium selenite, weights of the fasting rats were estimated then rats were anaesthetized using ether, blood samples were obtained from orbital sinus (sampling of controls taken in the estrus phase). After clotting at room temperature blood was centrifuged for 15 minutes at approximately $3000 \mathrm{rpm}$ [20]. The separated serum was stored at $-20^{\circ} \mathrm{C}$ until assayed.

\section{Macro anatomical examination:}

After taking blood samples, the animals were fixed on ventrodorsal position then by sterile scissor, their abdomens were opened under aseptic conditions to explore their genital tract.

The genital tracts were dissected from the surrounding visceral fat and ovaries were removed for macro morphological and macro morphometrical studies using a magnifier lens. Ovarian length, width and thickness were measured by Stainless MAUB calliper (Polond manufacture). Then ovarian and uterine weights were estimated using electrical balance (Germany).

\section{Micro morphological studies:}

Right ovaries were fixed in $10 \%$ buffered formalin for 6 hours at room temperature and washed in a phosphate buffer saline solution, fixed tissues were dehydrated in an ascending series of ethanol, cleared in xylene and embedded in paraffin. $5 \mu \mathrm{m}$ thick sections were mounted in slides previously treated with 3-aminopyropyl triethoxysilane and stained with hematoxylin and eoisin stain [21]

\section{Estimation of serum biochemical parameters:}

1- Rat enzyme linked immunosorbant assay (ELISA) kits were used to estimate level of 17 (3estradiol, progesterone, testosterone, Leutinizing Hormone (LH) according to the method described by Tietz et al., [22] (Cat: 2011-11-0175, 
2011-11-0742, 2011-11-5126 and 2011-11-0180; respectively), Follicular Stimulating Hormone (FSH) according to the method of Rebar et al., [23] (Cat:2011-11-0183). Kits were provided from Bio Source Europe S.A.-Rue de l'Industrie, Nivelles-Belgium, and insulin following the instructions of Starr et al., [24] (Cat: RAB0904, Sigma-Aldrich Chemie GmbH, U.S.A). OPN level was assayed according to kim et al., [25] (immune-biological laboratories Co, Japan; Cat: 27350) and C-Reactive Protein (CRP) according to the instruction of Kimberly et al., [26] (Lifespan Bioscience, USA. Cat: LS-F260391).

2- Glucose levels was assayed spectro-photometerically using glucose enzymatic (GOD-PAP)liquizyme Kits (Biotechnology, Egypt) [22]

$$
\text { Insulin }(\mu \mathrm{U} / \mathrm{mL}) \mathrm{X}
$$

Calculation of homeostasis model Glucose $(\mathrm{mg} / \mathrm{dl})$ assessment of IR (HOMA-IR)

$$
\frac{\text { Glucose }(\mathrm{mg} / \mathrm{dl})}{405}
$$

Statistical analysis: All data were expressed as mean \pm Standard Deviation (SD) for quantitative variables. The statistical analysis is done by using the Statistical Package for the Social Sciences (SPSS) program (Version 18 for Window 7). Multiple groups comparisons were carried using oneway ANOVA, followed by post hoc test. The association between different variables was analyzed using Pearson correlation test. $p<0.05$ was considered to be statistically significant.

\section{Results}

\section{Physical parameters:}

The results revealed a significant increase in body weight in PCO group and selinum treated PCO group in comparison to control group ( $p$ $<0.001)$. However, no significant change was observed between both groups.

Additionally, there was a significant decrease in uterine weight in PCO group when compared to control group $(p<0.001)$ which was significantly increased after selinum treatment in Group (III) $(p<0.001)$ in comparison to Group (II). In contrast, no significant change in ovarian weight was observed among all the studied groups $(p>0.05)$. Regarding the duration of esterous cycle, there was a significant prolongation in PCO group in comparison to control group which was significantly shortened after Se treatment when compared to

\begin{tabular}{|c|c|c|c|}
\hline Parameters & Group I & Group II & Group III \\
\hline • Body weight (g) & $265.6 \pm 7.69$ & $342.9 \pm 27.11^{\mathbf{a}}$ & $331.7 \pm 30.39^{\mathrm{a}}$ \\
\hline - Ovarian weight (g) & $0.31 \pm 0.57$ & $0.29 \pm 0.41$ & $0.30 \pm 0.74$ \\
\hline - Uterine weight (g) & $0.54 \pm 0.07$ & $0.32 \pm 0.08^{\mathbf{a}}$ & $0.49 \pm 0.05 \mathbf{b}$ \\
\hline $\begin{array}{l}\text { - Duration of estrous } \\
\text { cycle (days) }\end{array}$ & $4.50 \pm 0.63$ & $10.15 \pm 0.51^{\mathbf{a}}$ & $5.6 \pm 0.53 \mathbf{b}$ \\
\hline
\end{tabular}
untreated PCO group (Table 1).
Table (1): Physical parameters in all groups.

a: Significant versus Group I.

b: Significant versus Group II

\section{Serum parameters:}

Untreated PCO Group (II) revealed significant increase in the serum levels of OPN, testosterone, FSH, LH, and CRP compared to control Group (I) $(p<0.001,<0.001,<0.01,<0.001$, and $<0.001$ respectively). While, there were a significant decrease in estradiol and progesterone when compared to the same group $(p<0.001)$ (Table 2$)$.

However, treated PCO Group (III) revealed significant decrease in the levels of OPN, FSH, LH, CRP $(p<0.05)$, and testosterone $(p<0.001)$ accompanied by a significant increase in estradiol and progesterone $(p<0.001)$ when compared to Group (II).

On the other hand, in comparison to control Group (I), this group showed significant increase in serum levels OPN, testosterone, and CRP ( $p<$ $0.01,0.001$, and $<0.01$ respectively) and significant decrease in serum level of estradiol $(p<0.01)$, While, there was no significant change in levels of progesterone, FSH, LH between both groups. In addition, no significant change in glucose, insulin and calculated HOMA-IR was observed among all

\begin{tabular}{|c|c|c|c|}
\hline Parameters & Group I & Group II & Group III \\
\hline Osteopontien (ng/ml) & $36.02 \pm 4.2$ & $75.1 \pm 5.8^{\mathbf{a}}$ & $67.2 \pm 8.1 \mathbf{a}^{\mathbf{a}} \mathbf{b}$ \\
\hline Estradiole $(\mathrm{pg} / \mathrm{ml})$ & $38.97 \pm 2.5$ & $18.45 \pm 2.3^{\mathbf{a}}$ & $32.14 \pm 3.3 \mathbf{a , b}$ \\
\hline Progesterone $(\mathrm{ng} / \mathrm{ml})$ & $8.12 \pm 1.06$ & $5.78 \pm 1^{\mathbf{a}}$ & $7.85 \pm 0.9^{\mathbf{b}}$ \\
\hline $\mathrm{FSH}(\mu \mathrm{IU} / \mathrm{ml})$ & $3.9 \pm 0.31$ & $4.48 \pm 0.51^{\mathbf{a}}$ & $4.09 \pm 0.26^{\mathbf{b}}$ \\
\hline $\mathrm{LH}(\mu \mathrm{IU} / \mathrm{ml})$ & $2.24 \pm 0.36$ & $2.87 \pm 0.05^{\mathrm{a}}$ & $2.49 \pm 0.35 \mathbf{b}$ \\
\hline Testesterone (ng/ml) & $74.4 \pm 7.1$ & $225.2 \pm 11.06^{\mathbf{a}}$ & $187.3 \pm 7.8^{\mathbf{a}^{\prime} \mathbf{b}}$ \\
\hline Glucose (mg/dl) & $82.37 \pm 4.2$ & $81.02 \pm 3.1$ & $83.01 \pm 4.7$ \\
\hline INSULIN $(\mu \mathrm{IU} / \mathrm{mL})$ & $10.95 \pm 1$ & $11.2 \pm 0.7$ & $10.6 \pm 1.1$ \\
\hline HOMA-IR & $2.91 \pm 0.4$ & $3.7 \pm 0.37$ & $3.1 \pm 0.45$ \\
\hline $\mathrm{CRP}(\mu \mathrm{g} / \mathrm{ml})$ & $0.72 \pm 0.06$ & $1.87 \pm 0.07^{\mathbf{a}}$ & $1.55 \pm 0.2^{\mathbf{a}, \mathbf{b}}$ \\
\hline
\end{tabular}
the study groups (Table 2).

Table (2): Serum levels of all parameters in the studied groups.

a: Significant versus Group I.

b: Significant versus Group II

In addition OPN showed significant positive correlation with FSH, LH and CRP in both of Group II $(p<0.01,<0.01$, and $<0.001$, respectively) and Group III $(p<0.05)$, while, it showed significant 
negative correlation with estradiol and progesterone in Group II ( $p<0.05$ and $<0.01$; respectively) and Group III $(p<0.05)$. However, it showed insignificant correlation with testosterone, glucose, insulin and calculated HOMA-IR $(p>0.05)$ in all groups (Table 3).

Table (3): Pearson's correlation coefficient $(r)$ between serum osteopontin levels and the studied parameters within all groups.

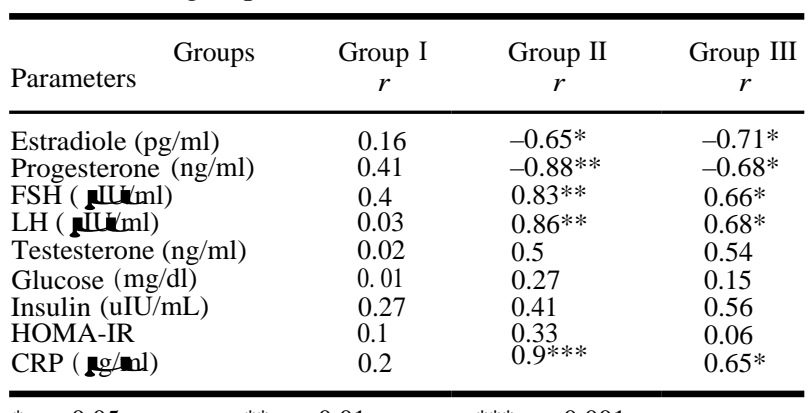

$*: p<0.05 . \quad$ * $\quad$ * $p<0.01 . \quad * * * p<0.001$.

Macro anatomical and micro-morphological studies:

In addition, macro morphological examination of the ovaries in control groups revealed that ovaries were located at the sub lumbar region caudal to the kidney. They have a grape like nodular appearance with pinkish to reddish colour with mean ovarian weight $(0.31 \mathrm{~g} \pm 0.57)$ and average dimensions $(4.7 \mathrm{~mm} \mathrm{X} 4 \mathrm{~mm}$ X $3.2 \mathrm{~mm})$. Moreover, their surfaces showed protruding mature graffian follicles with some reddish Corpora Lutea (CL) Fig. (1).

Micro morphological examination of ovaries in control group showed that ovarian cortex con- tains different stages of follicle development Fig. (2): Primary follicle (the earliest stage of development) was typically located under ovarian tunica albuginia. It was surrounded by single layer of simple squamous epithelium that may be changed into columnar one Fig. (3), secondary follicle: It was surrounded by multiple layers of proliferated granulosa cells (columnar epithelium) around the oocyte with appearance of zona pellucida between them Fig. (4), tertiary follicle: The spaces containing fluid between granulosa layers communicated to form large central cavity called follicular antrum filled by liquor folliculi. The oocyte is fixed with cumulus oophorus and surrounded with layer of corona radiate while the follicular theca is differentiated into theca externa and theca interna Fig. (5), accompanied by three or four groups of CL Fig. (1).

However, in PCO group macro anatomical examination detected the presence of several sub capsular cystic follicles accompanied by a well noticed decrease in width in the two uterine horns in comparison to control group Fig. (6). While, the histological examination of ovaries in the same group showed several numbers of cystic follicles surrounded by very thin layer of granulosa cells with no antral follicles or $\mathrm{CL}$ indicating anovulation Figs. $(7,8)$.

Interestingly, in selinum treated group, there was a decrease in the number of cystic follicles and increasing the number of the growing ovarian follicles through the stroma accompanied by appearance of a CL Figs. $(9,10)$.

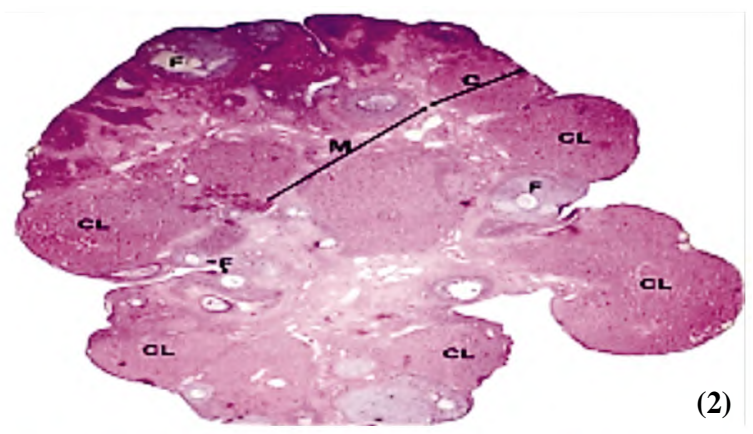

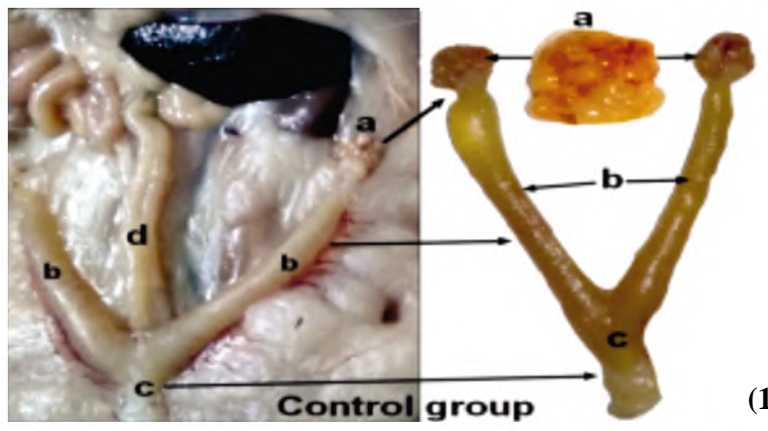
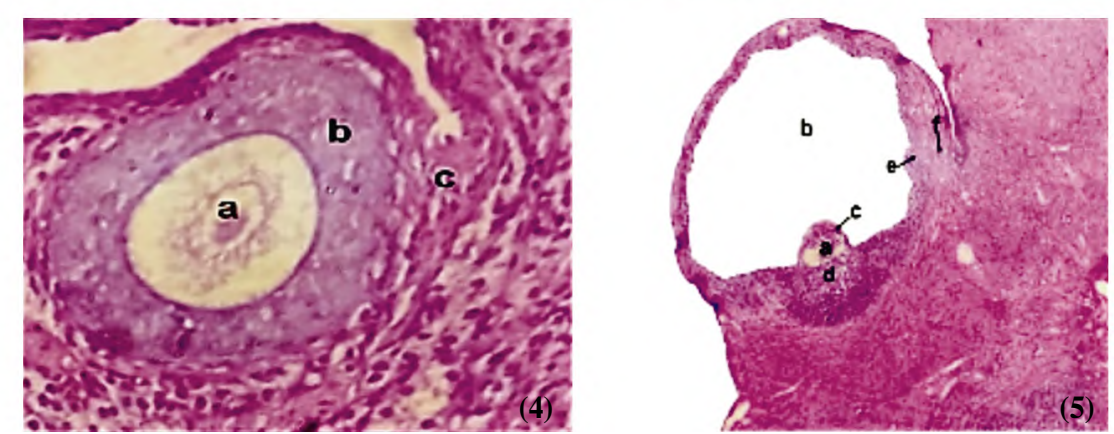

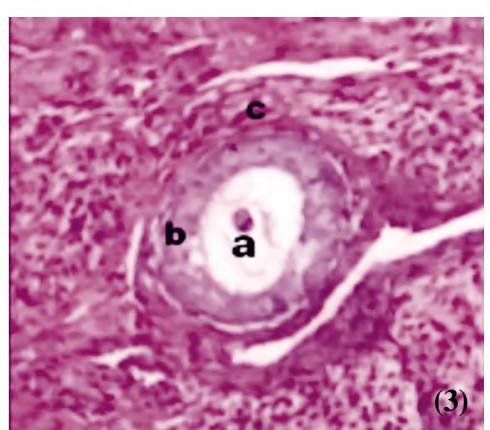



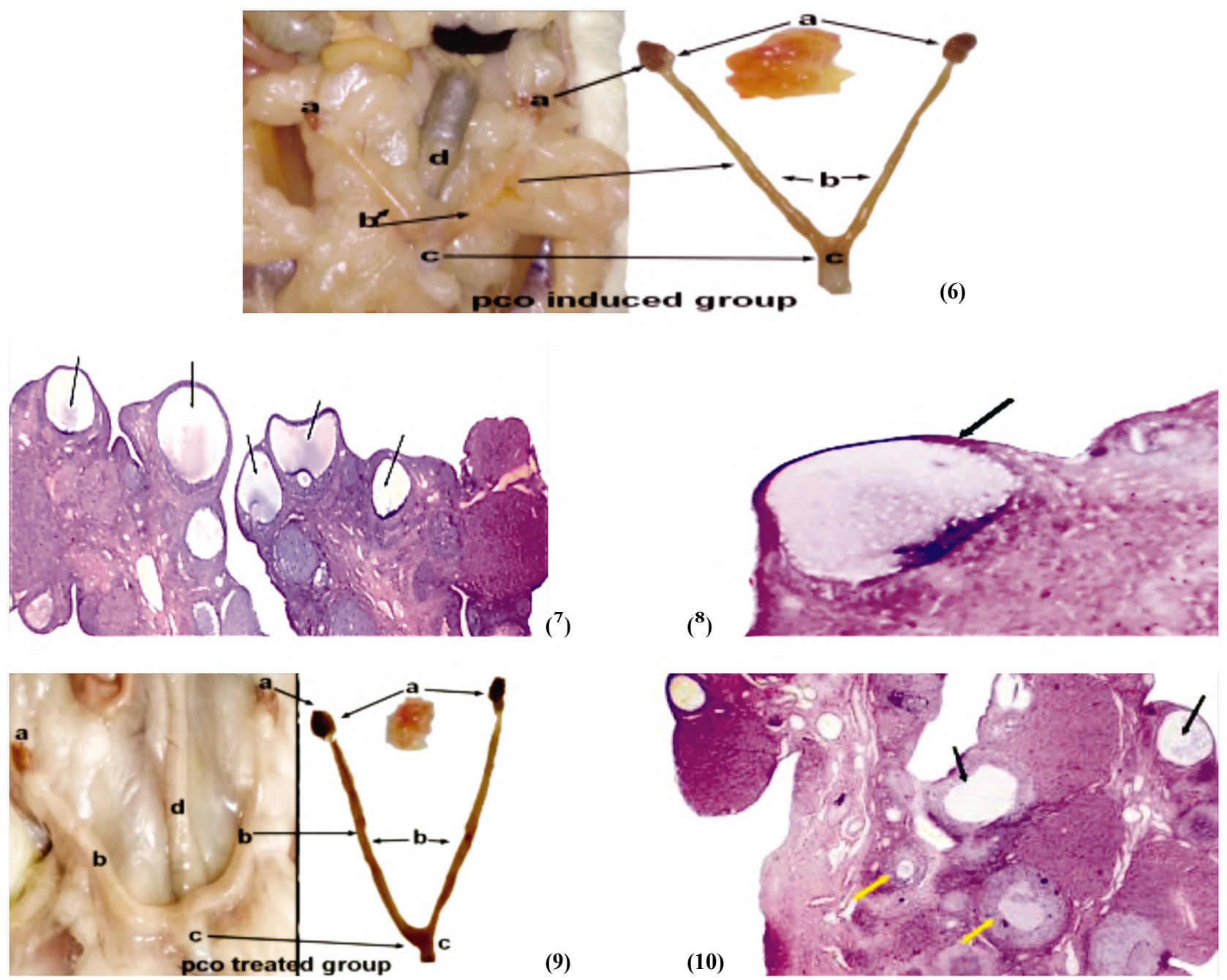

(9)

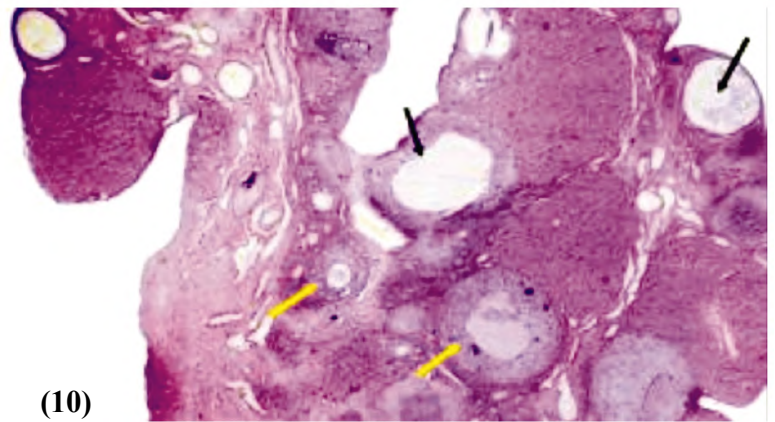

Figs. (1,6,9): Photomicrographs of insitu fresh female rat genitalia (left) and isolated dissected one (right) showing (a) ovary with grape like appearance, (b) uterine horns, (c) uterine body, (d) rectum of all studied groups. With appearance of several ovarian cysts externally in fig 6 (PCO group).

Fig. (2): A photomicrograph of normal ovarian section with the cortex (c) containing numerous follicles in different maturation stage (f) with protruded several bodies as Corpus Luteum (CL). The medulla contains several blood and lymphatic vessels and nerves (H \& E X4).

Fig. (3): A photomicrograph of the primary follicle showing (a) oocyte, (b) A layer of granulosa cells, (c) ovarian cortex (H \& E X10).

Fig. (4): A photomicrograph of the secondary follicle showing (a) oocyte, (b) several layers of granulosa cells, (c) ovarian cortex (H \& E X10).

Fig. (5): A photomicrograph of the tertiary follicle showing (a) oocyte, (b) follicular antrum (c) zonagranulosa and cronaradiata, (d) cumulus oophorus (e) theca interna and (f) theca externa (H \& E X10).

Fig. (7): A photomicrograph of ovarian section of PCO group showing several cysts (the arrows) and absence of CL (H \& E X4).

Fig. (8): A photomicrograph with high magnification of one ovarian cyst showing a fluid-filled cyst surrounded by single thin layer of granulosa cells (the arrow).

Fig. (10): A photomicrograph of ovarian section of PCO treated group showing a decrease in the number of cysts (black arrow) and several follicles begin to appear in different developmental stages (yellow arrows) (H \& E X4). 


\section{Discussion}

The results of the present study revealed that experimentally induced PCOS is similar to that of the human in several ways, this observation was in accordance with the results of Daneasa et al., [16] and Rajan et al., [28]

The development of PCOS in this study was evidenced by significant reduction of uterine weight despite having no significant effect on ovarian weight, accompanied by significant decrease in serum estradiol and progesterone levels, as well as significant elevation of testosterone, $\mathrm{LH}$ and FSH levels when compared to control group, which is confirmed by the micro morphological ovarian findings that showed variable number of sub capsular ovarian cysts and capsular thickening together with decreased number of CL or incomplete leutinization with lutenized cells distributed in crescent shape or as a thin layer of cells.

It was noticed by Daneasa et al., [16] that Letrozole could induce high androgen level and ovarian cysts by inhibiting androgen conversion to estrogen and promoting alteration of the hypothalamicpituitary-gonadal axis and high LH levels. Additionally, decreased progesterone levels are also indicative of anovulation [29]. This hormonal disturbance was responsible for irregular oestrous cycle and a persistent estrous phase caused the cysts to be filled with large amount of fluid which prevent the follicular growth [17]. Furthermore, eruption of ovarian follicles are controlled by progesterone and prostaglandins and alteration in these hormones cause un erupted follicles with or without leutinization [30].

Moreover, as uterine weight is regulated by estradiol, so their weight loss in loterazole onlytreated rats may be due to its low plasma levels [31].

Interestingly, Se administration in the present work caused significant increase in serum estradiol and progesterone in Group III accompanied by significant decrease in serum T, FSH and LH when compared to PCOS non treated group. It could be explained by its action on the granulosa cells by modulating their proliferation and estradiol synthesis [32] which was supported by an increase in the number of healthy growing follicles and the significant increase in uterine weight in this group.

This finding was also supported by the observation of Sakr et al., [33] who reported that Se protecting effect on folliculogenesis was responsible for recovery in ovarian steroidogenesis and normal functioning of the hypothalamo-hypophysial -ovarian axis which could be attributed to diminishing lipid peroxidation and oxidative stress, caspase 3 and cytochrome c28 inhibiting the apoptosis pathway in the ovary [34].

Moreover, Chattopadhyay et al., [31] noticed that Se prevents the ovarian and uterine weight loss induced by arsenic, and this may be due to the rapid distribution of Se to the ovary and uterus, which in turn may activate the selenium-dependent peroxidase activity which is one of the major components of ovarian antioxidant system.

However, Razavi et al., [35] and Hosseinzadeh et al., [36] did not observe any significant change in serum total testosterone after Se supplementation in PCOS patients.

In addition, our results revealed a significant increase in body weight in PCOS non treated and Se treated groups when compared to control group with no significant change between both groups. This observation was in accordance with this of Abdulghani et al., [37] who reported that increased concentration of testosterone in peripheral blood can be the reason of increased body weight of letrozole treated rats, and the increased body weight in those rats was not related to relative changes in body fat or lean body mass, but letrozole may stimulate general growth without affecting relative body composition [38] .

Furthermore, Jamilian et al., [14] observed that Se supplementation in PCOS patients had no effect on Body Mass Index (BMI) or dietary intake of energy.

It worth noticing that, in the present study there weren't any significant changes in serum glucose, insulin or HOMA-IR levels among all groups. This observation was in agreement with the previous findings of Rajan et al., [28] who found no significant change in oral glucose tolerance test as letrozole does not affect insulin signalling pathways, induce IR or reduce insulin sensitivity [39]

Additionally, Jamilian et al., [14] found that Se supplements to PCOS patients had no effect on plasma glucose level, however, it significantly decreased serum insulin levels and HOMA-IR. Unlike, Hosseinzadeh et al., [36] showed that Se supplementation worsened IR in PCOS patients.

Interestingly, in this study, there was a significant increase in OPN levels in Group (II) in comparison to control group which was in line with the results of Saklamaz et al., [40] who reported 
that increased circulating OPN levels in PCOS may be a compensatory mechanism to overcome a possible defect on OPN-mediated signaling pathway, and it is not clear whether increased OPN levels are primary activators or a result from the disorder.

Furthermore, androgen was shown to act on bone metabolism directly through androgen receptors, increasing the formation, differentiation and maturation of osteoblasts [41], which are a source for OPN secretion [42].

In addition, Dehdashtihaghighat et al., [43] and Palo et al., [44] stated that PCOS is considered a low-grade chronic inflammatory condition. Interestingly, OPN is a multifunctional pro-inflammatory cytokine that is able to promote inflammation and increased concentrations of OPN have been observed in inflammatory diseases [45] and itis expressed by inflammatory cells such as macrophages [46,47]. Also, Inoue and Shinohara [48] recognized that OPN controls immune cell functions including monocyte adhesion, migration, differentiation, and phagocytosis.

Moreover, OPN knockout mice exhibited diminished leukocyte recruitment at sites of inflammation. It worth noting that OPN is not only critical for macrophage recruitment, but also regulates the secretion of cytokines during cell-mediated immunity [8], as it activates the transcription factor nuclear factor (NF)- $\mathrm{KB}$ modulating the expression of a variety of inflammatory genes [49] and increasing tumor necrosis factor alpha (TNF- a) expression [50], which may explain the protective effect of OPN knockout and neutralization on adipose tissue inflammation [51].

Chronic low-grade inflammation in PCO is closely linked to endothelial inflammation and consequent endothelial dysfunction [52], as well as pro-inflammatory immune cell accumulation in adipose tissue [53]. It could be explained by increased CRP level which is not only an inflammatory marker of atherosclerosis, but also has direct deleterious effects on the vascular endothelium and decreases the production of nitric oxide as well [44]. Interestingly, in this study, serum level of CRP in PCOS group was significantly increased when compared to control group.

Which was in line with Dehdashtihaghighat et al., [43] who observed increased CRP in case of PCOS and they reported that this increase could be due to excess production in the liver under the influence of interleukin- 6 and TNF- $a$, but it was independent on BMI or IR and it could be due to hyperandrogenism in those patients, also, as reported by Gonzalez et al., [54] that is in lean reproductive age women, proatherognic and inflammatory markers increased after raising circulating androgens to levels observed in PCOS. However, the definite cause of CRP increase in PCOS is unknown.

In addition, the results in this work showed a significant positive correlation between both CRP and OPN in Group (II), so elevated OPN level added anew modulating factor for increased the inflammatory condition in case of PCOS.

Interestingly, rats receiving Se group exhibited a significant decrease in both OPN and CRP when compared to PCO untreated Group (II).

Furthermore, Toossi et al., [55] reported that Se compound can down regulate OPN expression with significant negative correlation between Se and OPN in healthy individuals and patients with psoriasis. The effect of Se on OPN level could be explained by its ability to decrease the formation of ROS and entry of $\mathrm{Ca}^{2+}$ in the leukocytes inhibiting neutrophil activation, the release of inflammatory factors and oxidative stress [11]

In accordance with these results, Razavi et al., [35] and Jalili et al., [56] noticed that administration of Se has reduced CRP among PCO and rheumatoid arthritis patients. Similar finding was also seen in centrally obese women who consumed selenium [57].

Se intake may decrease serum CRP levels through inhibiting the activation of NF-kB by modulating selenoprotein genes expression [58] and increasing endogenous selenoprotein biosynthesis [59].

As increased inflammatory factors in patients with PCOS render them at a potential increased risk for the development of infertility, and other comorbidities [60]. So, the decreased OPN and CRP levels after Se treatment could explain the improving effect of Se on the ovarian function in the present work.

In disagreement, no significant effect was observed on CRP levels after intake of cereal biscuit with selenized onion, for 2 months among healthy adults [61]

The discrepancy between any of our findings and those of others could be attributed to species differences and/or difference in selinum form, dose, duration and route of treatment. 
In addition, our results showed a significant positive correlation between serum OPN level and both LH and FSH accompanied by a significant negative correlation with estrogen and progesterone in Group II and III, with insignificant correlation with total testesterone which could be supported by the findings of Kuwabara et al., [62] who showed that OPN level and expression increased in mouse serum and ovarian granulose cells respectively in response to gonadotropin. Also Duleba and Dokras [49], revealed an insignificant correlation between OPN and androgen.

In summary, OPN involvement in PCOS enlarges the list of cytokines able to stimulate the inflammatory response in this disease and could disturb ovarian structure and function providing the possibility of using this inflammatory cytokine as new target in the treatment of PCOS as it provide a new mechanism by which Se treatment could improve pituitary-ovarian hormonal axis and ovarian micro morphological changes in letrazoleinduced PCOS rat model.

\section{References}

1- BOZDAG G., MUMUSOGLU S., ZENGIN D., KARABULUT E. and YILDIZ B.O.: The prevalence and phenotypic features of polycystic ovary syndrome: A systematic review and meta-analysis. Hum. Reprod., 31 (12): 284155, 2016.

2- LONDE P. and AGARWAL S.: Invitro phytochemical study on Berberisaristata root extracts: An effective neutraceutical for the treatment of polycystic ovarian syndrome. International Journal of Recent Scientific Research, 8 (9): 19934-40, 2017.

3- AZZIZ R.: PCOS in 2015: New insights into the genetics of polycystic ovary syndrome. Nat. Rev. Endocrinol., 12 (2): 74-5, 2016

4- LEGRO R.S., ARSLANIAN S.A., EHRMANN D.A., HOEGER K.M., MURAD M.H., PASQUALI R. and WELT C.K.: Diagnosis and treatment of polycystic ovary syndrome: An endocrine society clinical practice guideline. J. Clin. Endocrinol. Metab., 98 (12): 4565-92, 2013.

5- PALOMBA S., SANTAGNI S., FALBO A., La SALA G.B.: Complications and challenges associated with polycystic ovary syndrome: Current perspectives. N. Int. J. Womens Health, 7: 745-63, 2015.

6- PASQUALI R., DIAMANTI-KANDARAKIS E. and GAMBINERI A.: Management of endocrine disease: Secondary polycystic ovary syndrome: Theoretical and practical aspects. Eur. J. Endocrinol., 175: R157-R169, 2016.

7- HUGAR A.L., KANJIKAR A.P. and LONDONKAR R.L.: Polycystic Ovary Syndrome (PCOS)-A Mini Review. Gynecol., 3 (1): 000148, 2018.

8- SCATENA M., LIAW L. and GIACHELLI C.M.: Osteopontin: A multifunctional molecule regulating chronic inflammation and vascular disease. Arteriosclerosis, Thrombosis, and Vascular Biology, 27: 2302-9, 2007.
9- SUBRAMAN V., THIYAGARAJAN M., MALATHI N and RAJAN S.T.: OPN-revisited. Journal of Clinical and Diagnostic Research, 9: ZE10-ZE13, 2015.

10- KUWABARA Y., KATAYAMA A., TOMIYAMA R., PIAO H., KURIHARA S., ONO S., MINE K., AKIRA S., ORIMO H. and TAKESHITA T.: Gonadotropin regulation and role of ovarian osteopontin in the periovulatory period. J. Endocrinol., 224: 49-59, 2015.

11- KÖSE S.A. and NAZ1ROGLU M.: Selenium Reduces Oxidative Stress and Calcium Entry Through TRPV 1 Channels in the Neutrophils of Patients with Polycystic Ovary Syndrome. Biol. Trace. Elem. Res., 158: 136-42, 2014.

12-EL-SAMRA M.A. and AGGAG S.M.: Effects of Different Antioxidants on Sperm Parameters in Infertile Males. J.M.S.C.R., 6 (2): 752-61, 2018.

13- ASEMI Z., JAMILIAN M., MESDAGHINIA E. and ESMAILLZADEH A.: Effects of selenium supplementation on glucose homeostasis, inflammation, and oxidative stress in gestational diabetes: Randomized, double-blind, placebo-controlled trial. Nutrition, 31: 1235-42, 2015.

14- JAMILIAN M., RAZAVI M., FAKHRIE KASHAN Z., GHANDI Y., BAGHERIAN T. and ASEMI Z.: Metabolic response to selenium supplementation in women with polycystic ovary syndrome: A randomized, doubleblind,placebo-controlled trial. Clinical Endocrinology, 82: 885-91, 2015.

15-ZAFAR S.K., SIDDIQUI A., IQBAL SAYEED, AHMAD M., AHMAD M., SALIM S. and ISLAM F.: Dosedependent protective effect of selenium in rat model of Parkinson's disease: Neurobehavioral and neurochemical evidences. Journal of Neurochemistry, 84: 438-46, 2003.

16- DANEASA A., CUCOLAŞ C., LENGHEL L.M., OLTEANU D., ORASAN R. and FILIP G.A.: Letrozolevs estradiol valerate induced PCOS in rats: Glycemic, oxidative and inflammatory status assessment. Reproduction, 151 (4): 401-9, 2016.

17- SUN J., JIN C., WU H., ZHAO J., CUI Y., LIU H., WU L., SHI Y. and ZHU B.: Effects of electro-acupuncture on ovarian P450arom, $\mathrm{P} 450 \mathrm{c} 17 \mathrm{a}$ and mRNA expression induced by letrozole in PCOS rats. PLoS One, 8 (11): e79382, 2013

18- GOLDMAN J.M., MURR A.S. and COOPER R.L.: The rodent estrous cycle: Characterization of vaginal cytology and its utility in toxicological studies. Birth Defects Res. B. Dev. Reprod Toxicol., 80: 84-97, 2007.

19- KAFALI H., IRIADAM M., OZARDALI I. and DEMIR N.: Letrozole-induced polycystic ovaries in the rat: A new model for cystic ovarian disease. Archives of Medical Research, 35 (2): 103-8, 2004.

20- PAUL D., KEVIN A. JACOBS, GEOR R.J. and HINCHCLIFF K.W.: No Effect of Pre-exercise Meal on Substrate Metabolism and Time Trial Performance During Intense Endurance Exercise. International Journal of Sport Nutrition and Exercise Metabolism, 13: 489-503, 2003.

21- WEBSTER J.D., MILLER M.A., DuSOLD D. and RAMOS-VARA J.: Effects of Prolonged Formalin Fixation on Diagnostic Immunohistochemistry in Domestic Animals. J. Histochem. Cytochem., 57 (8): 753-61, 2009. 
22- TIETZ N.W., COOK T. and McNIVEN M.A.: Clinical Guide to Laboratory Tests, 3 rd edition. Pbl. W.B. Saunders, Co., Philadelphia, pp. 509-12, 1995.

23- REBAR R.W., MORANDINI I.C., PETZE J.E. and ERICKSON G.F.: Hormonal basis of reproductive defects in athymic mice: Reduced gonadotropins and testosterone in males. Biol. Repro., 5: 1267-76, 1982.

24- STARR J.I., MAKO M.E., JUHN D. and RUBENSTEIN A.H. : Measurement of serum pro-insulin-like material: Cross reactivity of porcine and human proinsulin. J. Lab. Clin. Med., 91: 691-2, 1978.

25- KIM J.H., SAKATES S.J., UEDE T. , WONG K.K., SCHORGE J.O., FELTMATE C.M., BERKOWITZ R.S., CRAMER D.W. and MOK S.C.: Osteopontin as a potential diagnostic biomarker of ovarian cancer. J.A.M.A., 287 (13): 1671-9, 2002.

26- KIMBERLY M.M., VESPER H.W., CAUDILL S.P., COOPER G.R., RIFAI N., DATI F. and MYERS G.L.: Standardization of immunoassay for measurement of high-sensitivity $\mathrm{C}$ reactive protein phase 1 : Evaluation of secondary reference materials. Clin. Chem., 49 (4): 611-6, 2003.

27- SUN C., ZHANG F., GE X., YAN T. , YAN T., CHEN X., SHI X. and ZHAI Q.: SIRT1 improves insulin sensitivity under insulin-resistant conditions by repressing PTP1B. Cell Metab., 6: 307-19, 2007.

28- RAJAN R.K., KUMAR M.S. and BALAJI B.: Soy isoflavones exert beneficial effects on letrozole-induced rat Polycystic Ovary Syndrome (PCOS)model through antiandrogenic mechanism, Pharmaceutical Biology, 55: 242$51,2017$.

29- SRIVASTAVA R.K. and KRISHNA A.: Pathophysiology of polycystic ovary syndrome (PCOS): Lessons from animal studies. Proc. India Natl. Sci. Acad., B71 (3): 191205, 2006.

30- TSUBOTA K., KUSHIMA K., YAMAUCHI K., MATSUO S., SAEGUSA T., ITO S., FUJIWARA M., MATSUMOTO M., NAKATSUJI S., SEKI J. and OISHI Y.: Collaborative work on evaluation of ovarian toxicity, effect of 2-4-week repeated dose studies and fertility study on indomethacin in female rats. J. Toxicol. Sci., 34: 129-36, 2009.

31- CHATTOPADHYAY S., PAL S.G., GHOSH D. and DEBNATH J.: Effect of Dietary Co-Administration of Sodium Selenite on Sodium Arsenite-Induced Ovarian and Uterine Disorders in Mature Albino Rats. Toxicological Sciences, 75 (2): 412-22, 2003.

32- SAID R.S., NADA A.S. and EL-DEMERDASH E.: Sodium Selenite Improves Folliculogenesis in RadiationInduced Ovarian Failure: A Mechanistic Approach. PLoSONE, 7 (12): e50928, 2012.

33- SAKR S.A., OKDAH Y.A. and IBRAHIM S.A.: Effect of Selenium on Carbendazim-Induced Ovarian Toxicity in Albino Rats: Histomorphometric and Histochemical Study. B.B.B., 4 (2): 728-41, 2014.

34- SAKR S.A., MAHRAN H.A. and NOFAL A.E.: Effect of selenium on carbimazole-induced testicular damage and oxidative stress in albino rats. J. Trace. Elem. Med. Biol., 25: 59-66, 2011.
35- RAZAVI M., JAMILIAN M., KASHAN Z.F., HEIDAR Z., MOHSENI M., GHANDI Y., BAGHERIAN T. and ASEMI Z.: Selenium Supplementation and the Effects on Reproductive Outcomes, Biomarkers of Inflammation, and Oxidative Stress in Women with Polycystic Ovary Syndrome. Horm. Metab. Res., 48 (3): 185-90, 2015.

36- HOSSEINZADEH F.M., HOSSEINZADEH-ATTAR M.J., YEKANINEJAD M.S. and RASHIDI B.: Effects of selenium supplementation on glucose homeostasis and free androgen index in women with polycystic ovary syndrome: A randomized, double blinded, placebo controlled clinical trial. J. Trace Elem. Med. Biol., 34: 56-61, 2016.

37- ABDULGHANI M., HUSSIN A.H., SULAIMAN S.A. and CHAN K.L.: The ameliorative effects of Eurycomalongifolia Jack on testosterone-induced reproductive disorders in female rats. Reprod. Biol., 12: 247-55, 2012.

38- MANNERÅS L., CAJANDER S., HOLMÄNG A., SELESKOVIC Z., LYSTIG T. , LÖNN M. and STENERVICTORIN E.: A New Rat Model Exhibiting Both Ovarian and Metabolic Characteristics of Polycystic Ovary Syndrome. Endocrinology, 148 (8): 1 3781-91, 2007.

39- WALTERS K.A., ALLAN C.M. and HANDELSMAN D.J.: Rodent models for human polycystic ovary syndrome. Biol. Reprod., 86: 12-11, 2012.

40- SAKLAMAZ A., CALAN M., YILMAZ O., KUME T., TEMUR M., YILDIZ N., KASAP E., GENC M., YUREKLI B.S. and KOCABAS G.U.: Polycystic ovary syndrome is associated with increased osteopontin levels Eur. $\mathbf{J}$. Endocrinol., 174: 415-23, 2016.

41- KATULSKI K., SLAWEK S., CZYZYK A., PODFIGURNA-STOPA A., PACZKOWSKA K., IGNASZAK N., PODKOWA N. and MECZEKALSKI B.: Bone mineral density in women with polycystic ovary syndrome. Journal of Endocrinological Investigation, 37 (12): 1219-24, 2014.

42- FLORENCIO-SILVA R.F., Da SILVA SASSO G.R., SASSO-CERRI E., SIMÕES M.J. and SÉRGIO CERRI: Biology of Bone Tissue: Structure, Function, and Factors That Influence Bone Cells. Biomed. Res. Int., 2015: 421746, 2015.

43- DEHDASHTIHAGHIGHAT S., MEHDIZADEHKASHI A., ARBABI A., PISHGAHROUDSARI M., PISHGAHROUDSARI M. and CHAICHIAN S.: Assessment of C-reactive Protein and C3 as Inflammatory Markers of Insulin Resistance in Women with Polycystic Ovary Syndrome: A Case-Control Study. J. Reprod. Infertil., 14 (4): 197-201, 2013.

44- PALO I. and MISHRA S.K. : Evaluation of the highsensitivity C-reactive protein in young obese women with PCOS. J. Evid. Based. Med. Healthc., 5 (1): 80-4, 2018.

45- ZEYDA M., GOLLINGER K., TODORIC J., KIEFER F.W., KECK M., ASZMANN O., PRAGER G., ZLABINGER G.J., PETZELBAUER P. and STULNIG T.M.: Osteopontin is an activator of human adipose tissue macrophages and directly affects adipocyte function. Endocrinology, 152: 2219-27, 2011.

46- LUND S.A., WILSON C.L., RAINES E.W., TANG J., GIACHELLI C.M. and SCATENA M.: Osteopontin mediates macrophage chemotaxis via alpha4 and alpha9 integrins and survival via the alpha4 integrin. Journal of Cellular Biochemistry, 114: 1194-202, 2013. 
47- TARDELLI M., ZEYDA K., MORENO-VIEDMA V., WANKO B., GRÜN N.G., STAFFLER G., ZEYDA M. and STULNIG T.M.: Osteopontin is a key player for local adipose tissue macrophage proliferation in obesity. Molecular Metabolism, 5 (11): 1131-7, 2016.

48- INOUE M. and SHINOHARA M.L.: Intracellular osteopontin (iOPN) and immunity. Immunologic Research, 49: 160-72, 2011.

49- AHMED M. and KUNDU G.C.: Osteopontin selectively regulates $\mathrm{p} 70 \mathrm{~S} 6 \mathrm{~K} / \mathrm{mTOR}$ phosphorylation leading to NFkappaB dependent AP-1-mediated ICAM-1 expression in breast cancer cells. Molecular Cancer, 9: 101-8, 2010.

50- AVELEIRA C.A., LIN C.M., ABCOUWER S.F., AMBRÓSIO A.F. and ANTONETTI D.A.: TNF- a Signals Through PKC $\zeta / N F-\kappa B$ to Alter the Tight Junction Complex and Increase Retinal Endothelial Cell Permeability. Diabetes, 59 (11): 2872-82, 2010.

51- KIEFER F.W., ZEYDA M., GOLLINGER K., PFAU B., NEUHOFER A., WEICHHART T., SÄEMANN M.D., GEYEREGGER R., SCHLEDERER M., KENNER L. and STULNIG T.M.: Neutralization of osteopontin inhibits obesity-induced inflammation and insulin resistance. Diabetes, 59: 935-46, 2010.

52- DULEBA A.J. and DOKRAS A.: Is PCOS an inflammatory process? Fertil. Steril., 97 (1): 7-12, 2012.

53- SPRITZER P.M., LECKE S.B., SATLER F. and MORSCH D.M.: Adipose tissue dysfunction, adipokines, and lowgrade chronic inflammation in polycystic ovary syndrome. Reproduction: 149: 219-27, 2015.

54- GONZÁLEZ F., SREEKUMARAN N., BASAL E., BEARSON D., SCHIMKE J. and BLAIR H.: Induction of Hyperandrogenism in Lean Reproductive-Age Women Stimulates Proatherogenic Inflammation. Horm. Metab. Res., 47 (06): 439-44, 2015.

55- TOOSSI P., SADAT AMINI S.H., SADAT AMINI M.S., PARTOVI K.M., ENAMZADE R., KAZEMINEJAD A., ESMAEILY RADVAR S. andYOUNESPOUR S.: Assessment of serum levels of osteopontin, selenium and prol- actin in patients with psoriasis compared with healthycontrols, and their association with psoriasis severity. Clin. Exp. Dermatol., 40 (7): 741-6, 2015

56- JALILI M., KOLAHI S., AREF-HOSSEINI S.R., MAMEGANI M.E. and HEKMATDOOST A.: Beneficial role of antioxidants on clinical outcomes and erythrocyte antioxidant parameters in rheumatoid arthritis patients. Int. J. Prev. Med., 5: 835-40, 2014.

57- ALIZADEH M., SAFAEIYAN A., OSTADRAHIMI A., ESTAKHRI R., DANEGHIAN S., GHAFFARI A. and GARGARI B.P.: Effect of 1-arginine and selenium added to a hypocaloric diet enriched with legumes on cardiovascular disease risk factors in women with central obesity: A randomized, double-blind, placebo controlled trial. Ann. Nutr. Metab., 60: 157-68, 2012.

58- HE Y.T., LIU D.W., DING L.Y., LI Q. and XIAO Y.H.: Therapeutic effects and molecularmechanisms of antifibrosis herbs and selenium on rats with hepatic fibrosis. World J. Gastroenterol., 10: 703-6, 2004.

59- DUNTAS L.H. Selenium and inflammation: Underlying anti-inflammatory mechanisms. Horm. Metab. Res., 41: 443-7, 2009.

60- PAWELCZAK M., ROSENTHAL J., MILLA S., LIU Y.H. and SHAH B.: Evaluation of the Proinflammatory Cytokine Tumor Necrosis Factor-alpha in Adolescents with Polycystic Ovary Syndrome. J. Pediatr. Adolesc. Gynecol., 27: 356-9, 2014.

61- MADARIC A., KADRABOVA J., KRAJCOVICOVAKUDLACKOVA M., MISLANOVA C., KAJABA I. and BLAZICEK P.: The effect of bioactive complex of quercetin, selenium, catechins and curcumin on cardiovascular risk markers in healthy population after a two month consumption. Bratisl. Lek. Listy, 114: 84-7, 2013.

62- KUWABARA Y., KATAYAMA A., TOMIYAMA R., PIAO H., KURIHARA S., ONO S., MINE K., AKIRA S., ORIMO H. and TAKESHITA T.: Gonadotropin regulation and role of ovarian osteopontin in the periovulatory period. Journal of Endocrinology, 224: 49-59, 2015. 


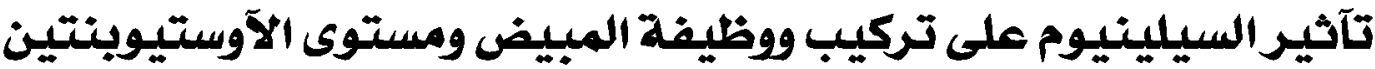

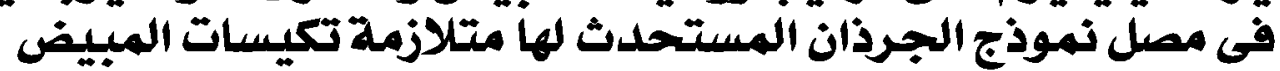

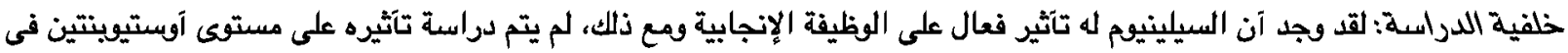

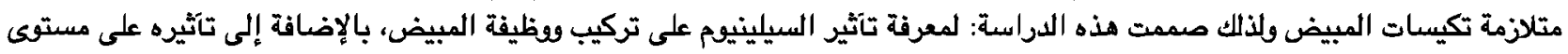

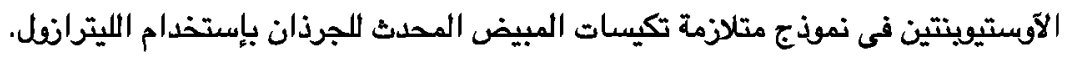

المواد والطرق: تم إستخدام ثلاثين من إناث الفئران البيضاء وتم تقسيمها إلى ثلاث مجموعات متساوية:

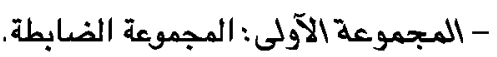
- المجموعة الثانية: مجموعة متلازمة تكيسات المبيض المجية المستعدئة.

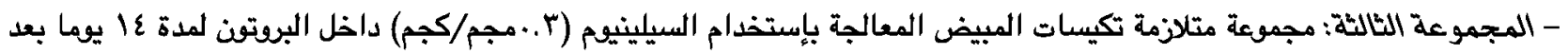

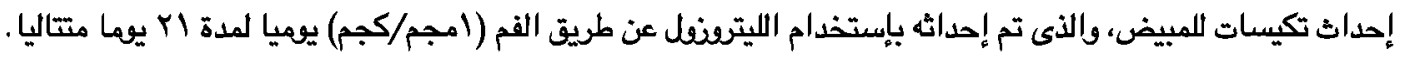

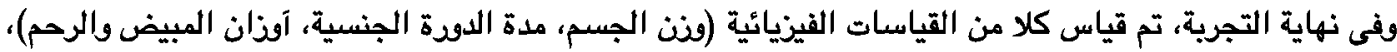

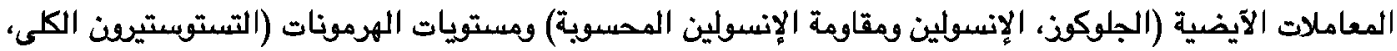

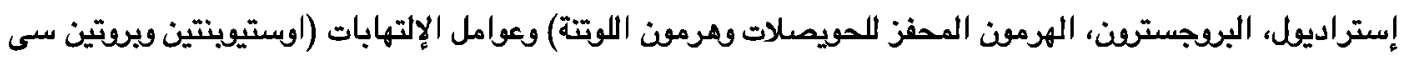

التفاعلى (CRP)) وكذالك تم عمل دراسة تشريحية ميكروسكوبية شاملة للمييضين.

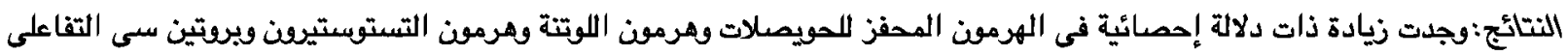

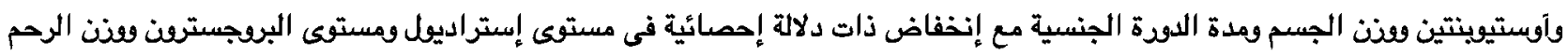

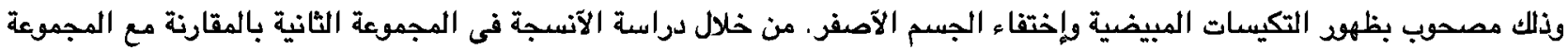

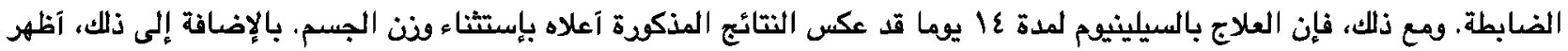

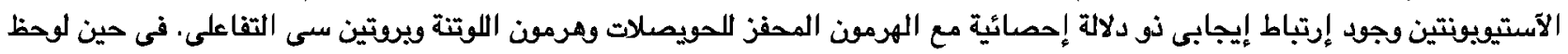

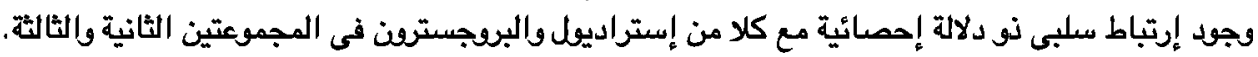

الخلاصة: العلاج بالسيلينيوم له آثار مفيدة فى الجرذان التى إستحدث لها متلازمة تكيسات المبايض التى قد تعزى إلى قدرته المضادة 